\title{
Reproductive Biology and Fruit Setting of Passiflora quadrangularis L. (Giant Granadilla) in East Malaysia
}

\author{
Nur Shahirah Shahbani ${ }^{1}$, Shiamala Devi Ramaiya ${ }^{1 *}$, Noorasmah Saupi ${ }^{1}$, Japar \\ Sidik Bujang ${ }^{2}$ and Muta Harah Zakaria ${ }^{3}$
}

${ }^{1}$ Department of Crop Science, Faculty of Agriculture and Food Sciences, Universiti Putra Malaysia Bintulu Campus, 97008 Bintulu, Sarawak, Malaysia

${ }^{2}$ Department of Biology, Faculty of Science, Universiti Putra Malaysia, 43400 UPM Serdang, Selangor Darul Ehsan, Malaysia

${ }^{3}$ Department of Aquaculture, Faculty of Agriculture, Universiti Putra Malaysia, 43400 UPM Serdang, Selangor Darul Ehsan, Malaysia

\begin{abstract}
Passiflora quadrangularis L., also known as giant granadilla, belongs to the family Passifloraceae together with the well-known species Passiflora edulis Sims. This species has received attention from growers in recent years due to its aromatic flowers, unique and excellent fruit flavor and phytotherapeutic properties. Despite the numerous health benefits of this Passiflora species, information on their agronomical features and production is scarce. Therefore, the objective of this study was to examine the reproductive biology and fruit setting of $P$. quadrangularis cultivated in Sarawak, Malaysia. The findings revealed

ARTICLE INFO

Article history:

Received: 10 February 2020

Accepted: 13 November 2020

Published: 27 November 2020

DOI: https://doi.org/10.47836/pjtas.43.4.16

E-mail addresses:

shahirahshahbani@gmail.com (Nur Shahirah Shahbani)

shiamala@upm.edu.my (Shiamala Devi Ramaiya)

noorasmah@upm.edu.my (Noorasmah Saupi)

japar@upm.edu.my (Japar Sidik Bujang)

muta@upm.edu.my (Muta Harah Zakaria)

*Corresponding author

that the giant granadilla was a steady-state species that produced flowers lasting for only one day. Passiflora quadrangularis started to produce flowers 3 months after transplantation, followed by fruiting two months after anthesis. In East Malaysia, the flowers started blooming at dawn (0625 \pm 0.17 hours) followed by anthesis at $0806 \pm 0.23$ hours and remained open until sunset. In contrast to $P$. edulis which flowered all year round, this species only
\end{abstract}


exhibited two peaks, with a minor peak recorded from January-March and a major peak from September-December, coinciding with warm temperatures and moderate rainy season. Good fruit yields were recorded which was attributed to the ability for self-pollination due to autogamy and geitonogamy, in addition to the presence of effective pollinators. The yearly production of $P$. quadrangularis, produced relatively larger fruit with weights ranging from 884.4-2892.7 g, was $20,151.36 \mathrm{~kg} \mathrm{ha}^{-1}$ (8993 fruits). Detailed information on the reproductive behavior of $P$. quadrangularis growing in local climates can be used for commercial cultivation and future breeding studies.

Keywords: Floral, giant granadilla, Passiflora quadrangularis, passion fruit, phenology, selfpollination

\section{INTRODUCTION}

Passion flowers are known to be one of the most alluring and appealing plants in the tropics. They produce exotic flowers that are unique and extremely mesmerizing (Ulmer \& MacDougal, 2004). Passiflora L. consists of more than 500 species and is the largest genus in the Passifloracea family (Perez et al., 2007). Passiflora species are mainly distributed in the Neotropics and only 23 species are native in Southeast Asia, Australia and Oceania (Perez et al., 2007; Ulmer \& MacDougal, 2004). The genus has approximately 50 species that bear edible fruits, however only two species; $P$. edulis
Sims (purple passion fruit) and P. edulis $\mathrm{f}$. flavicarpa (yellow passion fruit), are widely cultivated for fresh fruit and juice production (Patel et al., 2011). In addition, the lesser known Passiflora quadrangularis L., known as the giant granadilla, is also cultivated on a small scale for local consumption in certain countries (Kishore et al., 2010) including Malaysia.

The world production of passion fruit increased from 1.05 million MTs in 2005 to 1.47 million MTs in 2017 (Altendorf, 2018), with the market price in Malaysia ranging from RM 15-16/kg. The current passion fruit market has a tendency towards healthy and functional products at affordable prices. Passion fruit juice is highly concentrated, and it makes a highly palatable beverage when diluted and sweetened (Das et al., 2013). The juice is preferably consumed alone or mixed with other fruit juices to improve the aroma. The demand for passion fruit has increased not only because of its organoleptic properties but also due to its essential nutrient composition, multivitamin content and antioxidant properties (Li et al., 2016; Phamiwon et al., 2016; Ramaiya et al., 2019). In many countries (i.e., India, Brazil and the United States) the juice is also used for flavour in many food products, such as desserts, jam, jelly, ice-cream and yogurt (Joy, 2010; Salazar et al., 2016; Shivanna, 2012;). Apart from its edible uses, passion fruit also possesses considerable medicinal properties. Passiflora species are rich in phytochemicals, e.g., flavonoids, tannins, phenols, glycosides, fatty acids and alkaloids (Ingale \& Hivrale, 2010). These essential 
elements are used in anti-inflammatory ( $\mathrm{Li}$ et al., 2016), anticonvulsant, antimicrobial (Ripa et al., 2009), anticancer (Martina et al., 2007) and anti-diabetic (Phamiwon et al., 2016) treatments to treat osteoarthritis (Min et al., 2011) and insomnia (Fructose et al., 2017) because of their high antioxidant effects (Martinez et al., 2012).

Passion fruit was first planted in Malaysia by the Department of Agriculture in Negeri Sembilan in 1914. Then in 1960, it was planted for commercial purposes in Johor and Pahang (Chai, 1979). However, disease outbreaks affected the production and restricted further expansion of the use of fruit for commercial production. Passion fruit has the potential to be produced on a large scale in Malaysia as the local climate of this country is ideal for growing this fruit (Ramaiya et al., 2013). To date, only 8 species have been recorded in Malaysia with two widely cultivated species; the purple and yellow passion fruit. Recently, the non-native $P$. quadrangularis has gained attention from local growers due to its relatively large fruit size $(\sim 1-3 \mathrm{~kg})$ (Ramaiya et al., 2013), aromatic flavor and health benefits (Das et al., 2013). This species has been cultivated on a small scale locally and internationally and it is the only passion fruit that bears edible mesocarp (Catalina et al., 2018).

It is important to study the adaptability and biology of P. quadrangularis. This plant is not native to Malaysia and it has been claimed that plants from different geographical locations can produce plants phenotypically different from those in their native environment (Gratani, 2014). Success in plant adaptability is reflected in the quantity and quality of the offspring produced. However, this process is not simple and producing well-adapted flowering plants involves complex ecological interactions between species and the environment, which affect plant phenology and physiology. In addition, the features of plants are not only caused by their genetic properties but also highly influenced by external factors such as geographic regions, climate conditions, and the availability of nutrients and pollinators (Catalina et al., 2018; Morellato and Haddad, 2000). To date, no published data is available on the cultivation and use of $P$. quadrangularis in Malaysia. Therefore, the objective of this study was to examine the reproductive biology and fruit setting of $P$. quadrangularis cultivated in Sarawak, EastMalaysia. Knowledge of the plant biology of this non-native species is crucial for local management and commercial production.

\section{MATERIALS AND METHODS}

\section{Study Location and Plant Cultivation}

The experiment was conducted at the passion fruit farm at Universiti Putra Malaysia Bintulu Campus (N 03 $12.45^{\prime}$, E $113^{\circ}$ $\left.4.68^{\prime}\right)$, Sarawak. The soil was categorized as Bekenu series, (Typic Paleudults) with a sandy loam texture and the $\mathrm{pH}$ was 5.36 for depths of $0-15 \mathrm{~cm}$. The monthly weather data on rainfall and temperature obtained from the Malaysian Meteorological Department, Sarawak Branch (Kuching, Sarawak) is presented in Figure 1. The means temperature of the region ranged 
from $26^{\circ} \mathrm{C}$ to $28.0^{\circ} \mathrm{C}$. The monthly rainfall varied from $94.8 \mathrm{~mm}$ to $638.8 \mathrm{~mm}$.

The planting materials used in this study were cuttings collected from Gold Rabbit Farm, Bintangor (N 02 $32.71^{\prime}$, E 111.6 $\left.6^{\circ} 56.9^{\prime}\right)$, Sarawak, where passion fruit is planted at a commercial scale. Vertical trellis system with twenty rows, each $25 \mathrm{~m}$ long, was constructed. The trellis system consisted of $2.0 \mathrm{~m}$ tall posts set at $5 \mathrm{~m}$ intervals along the rows. Three-gauge galvanized wires were strung along the rows and attached to the posts. Five months-old seedlings were chosen for transplanting and a planting distance of $2.0 \times 2.5 \mathrm{~m}$ was used. Plant maintenance, consisting of weeding, fertilization, and pruning, was performed accordingly.

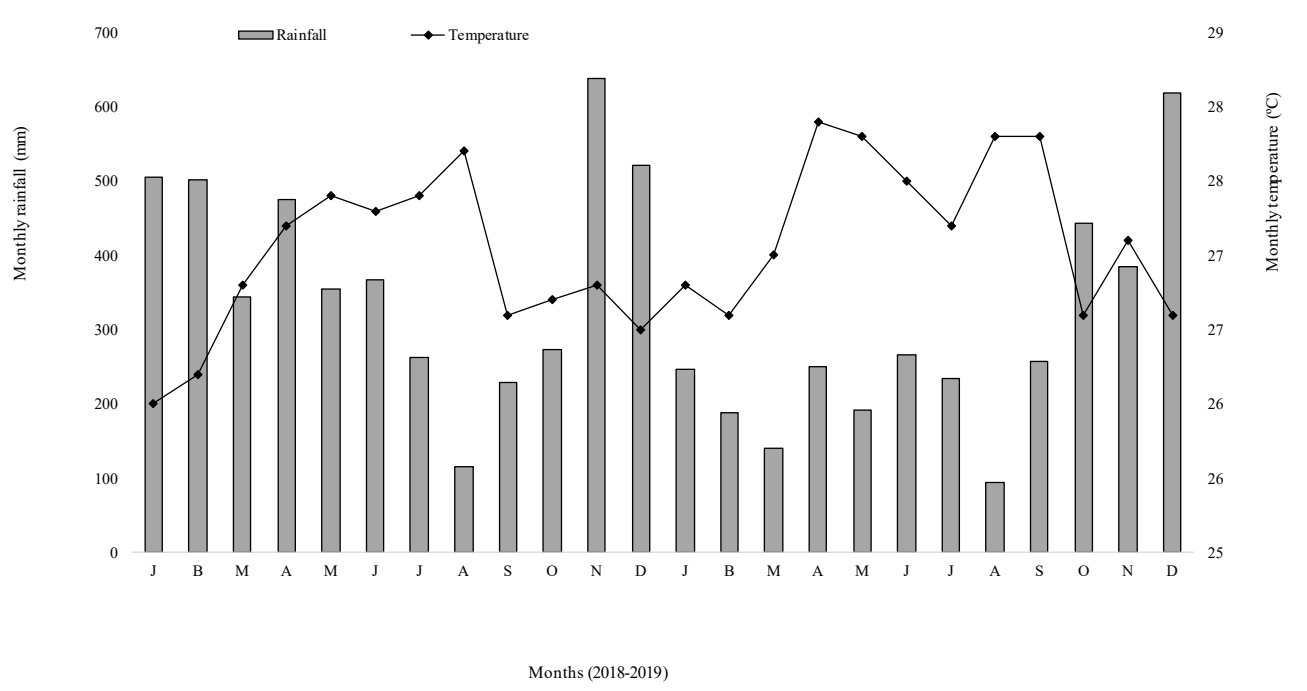

Figure 1. Meteorological data for monthly rainfall and temperature year 2018 and 2019

\section{Observation of Phenology and Fruits Productivity}

The vegetative shoots were tagged and their developmental changes were observed up to the fruiting stage. The phenological records were correlated with metrological data (i.e., monthly rainfall and temperature). The plant development stages recorded in this experiment were based on the extended $\mathrm{BBCH}$ scale-Growth stages of mono-and dicotyledonous plants (Meier et al., 2009).
The observations that were recorded were the occurrence, duration and frequency of vegetative growth, flower blooming and fruit setting. The major bloom and minor bloom were classified based on the number of flowers open per day. Major blooms were characterized as more than half of the vines producing five or more flowers per day for 10 days in a month (Kishore et al., 2010), whereas the minor bloom referred to less than half of the vines producing less than 
5 flowers per day for at least 5-10 days per month. Additionally, detailed observations of the flowering phenology, blooming time, changes in the position of pistil and stamen and time of anthesis until the flowers closed were recorded. The initial fruit set was observed after 3 days of pollination. If pollution is successful, the flower ovary will begin to enlarge within 3 days (Das et al., 2013). The fruit development and ripening stages were also recorded. The total production was calculated on a hectare basis.

\section{Pollinator and Nectar Composition}

The insects visiting the $P$. quadrangularis flowers were collected, photographed, and identified with the taxonomic keys from Gonzalez et al. (2009). Observations were carried out from the pre-anthesis stage until anthesis was complete. Additionally, the nectar composition of $P$. quadrangularis flowers was examined using High Performance Liquid Chromatography (HPLC) following method by Shaffiq et al. (2013). The flowers of $P$. quadrangularis were randomly collected during blooming and immediately brought to the laboratory. The flowers were then dissected, the nectar was extracted using a sterile micropipette, and the volume was recorded for individual flowers. The nectar was kept in microcentrifuge tubes and stored at $4^{\circ} \mathrm{C}$ prior to sugar analysis. A total of $20 \mu \mathrm{L}$ nectar was diluted to a ratio of 1:100 with a mobile phase consisting of ultrapure water with $0.0001 \mathrm{M}$ Ca-EDTA.
Three stock standard sugar solutions (HPLC grade $\geq 99.5 \%$ ), namely sucrose, glucose and fructose, were prepared in the mobile phase. Prior to injection, the standard solutions and nectars were passed through a membrane filter with a 0.45 $\mu \mathrm{m}$ pore size and $10 \mu \mathrm{L}$ was used per injection. The sugar compositions were determined by HPLC system (Waters Corp., Milford, MA, USA) equipped with a Waters Delta 600 pump controller and an in-line degasser AF connected with a Waters 2414 refractive index detector. A Waters SugarPak I column (300 x $6.5 \mathrm{~mm})$, packed with a microparticulate cation-exchange gel in calcium form was used in this study. The flow rate was $0.4 \mathrm{~mL} \mathrm{~min}^{-1}$ in the optimized working phase. The optimized temperature of the detector was $40^{\circ} \mathrm{C}$ and the column was set at $70^{\circ} \mathrm{C}$. The sugar compounds in nectar were identified by comparing their retention times. The standard retention times for sucrose, glucose and fructose were 10.3, 12.7 and $15.1 \mathrm{~min}$, respectively.

\section{RESULTS AND DISCUSSION}

\section{Passiflora quadrangularis Flower Blooming}

The flowering of $P$. quadrangularis is classified as "steady-state"; meaning that this species exhibits constant production of few flowers each day with each flower lasting only one day. The flowers of this species are solitary, produce relatively stronger fragrances and faced downward. Five main stages were recognized in $P$. quadrangularis flower development; stage 
1-bracts formation, stage 2-bud initiation, stage 3-bud development, stage 4-complete bud formation, and stage 5-flower blooming. The first flower bloom in P. quadrangularis was observed on 5 September 2019, 4 months after transplanting. The first bloom occurred 122 days after transplanting. This species required a slightly longer period (16.8 \pm 0.84 days) than that of other species, e.g., P. edulis (13.4 \pm 0.55 days), before flowers opened after their appearance. Montero et al. (2013) reported that the development time of the flower buds was 13 days and differed in areas outside the native range of Brazil, the plant at 16-18 days in Malaysia and 21 days in Venezuela (Haddad \& Figueroa, 1972). The maximum size of the flower bud recorded in this study was $6.45 \pm 0.07$ $\mathrm{cm}$. Flowers of this species started to open early in the morning ( $0615 \pm 0.12$ hours $)$ and the flowers remained opened until sunset at approximately 1600-1700 hours. This is contradictory to $P$. edulis in which the flowers are in full bloom from 1215 to 1340 hours in a local tropical climate (Ramaiya et al., 2020). Full flower blooming was recorded at approximately $0715 \pm 0.20$ hours, and it took approximately $30 \mathrm{~min}$ for the styles to be completely curved and be in contact with the anthers, with anthesis starting at $0815 \pm 0.23$ hours.

\section{Flower Blooming Stages and Stigma and Anther Positions}

In Passiflora flowers, the position and movement of the stigma and anther are very important for the role of self-pollination (Banu et al., 2009). Three phenological stages have been recognized in flowers of $P$. quadrangularis. In this study, no significant changes in color or odor was observed in any stage of flower development. Phase 1 is known as pre-anthesis. During this time, which corresponds to the stage immediately preceding anthesis, the flowers are in the bud stage. At this stage, the reproductive structure was not visible; the gynoecium and androecium were positioned towards the center of the flower and were fully covered by the sepals.

Phase 2 is known as flower homogamy and herkogamy. Generally, Passiflora flowers are homogamous, with the anthers and stigmas maturing simultaneously, and present herkogamy, leading to a spatial separation of the anthers and stigma. During this stage, the flowers started to open, the reproductive structures were fully exposed to the external environment, and the sepals, petals and corona spread out rapidly. During flower opening, the upright facing anthers drooped, causing the dehisced side of the anther to face downward. The styles which are in an upright position began to tilt until the receptive stigmas came into contact with the anthers, thereby transferring pollen grains onto the stigma surface. In Passiflora flowers, this important phenomenon reduces the distance between the stigmas and anthers, which aid in successful pollination. As the pollen grains were large and white, the presence of pollen grains on the stigma surface could be clearly seen. 
Additionally, during stage 2 of flower blooming, P. quadrangularis flowers exhibited 3 types of style curvature: a) styles without curvature (WC), in which the styles stand erect; b) partially curved (PC) styles, in which the styles are partially curved and stigmas do not touch the anthers; and c) completely curved (CC) styles in which the styles are fully curved and the stigma was in contact with the anther. The percentage (\%) of the different types of styles in P. quadrangularis flowers are presented in Figure 2. The majority of the flowers exhibited the CC style (80.00\%), which provided assurance for successful reproduction in P. quadrangularis. The WC flowers were relatively less common, as such flowers do not get pollinated and bear fruits $(6.67 \%)$.
Phase 3 is known as flower senescence; and during this time, the closure of the flower occurs. The petals and corona wilted, and the surfaces lost turgidity and started closing. The sepals returned to an upright position while the stigmas shifted backward, and the bracts remained attached. The pollinated flowers showed rapid enlargement of the ovary and developing fruit could be observed in 3 days. Non-pollinated flowers were abscised within 2-3 days without showing enlargement of the ovary.

In its native habitat and most of the other places in the world, Passiflora species are thought to be self-incompatible, and carpenter bees help to pollinate the flowers (Bruckner et al., 1995; Catalina et al., 2018; Madureira et al., 2014). In addition to the presence of effective pollinators, the

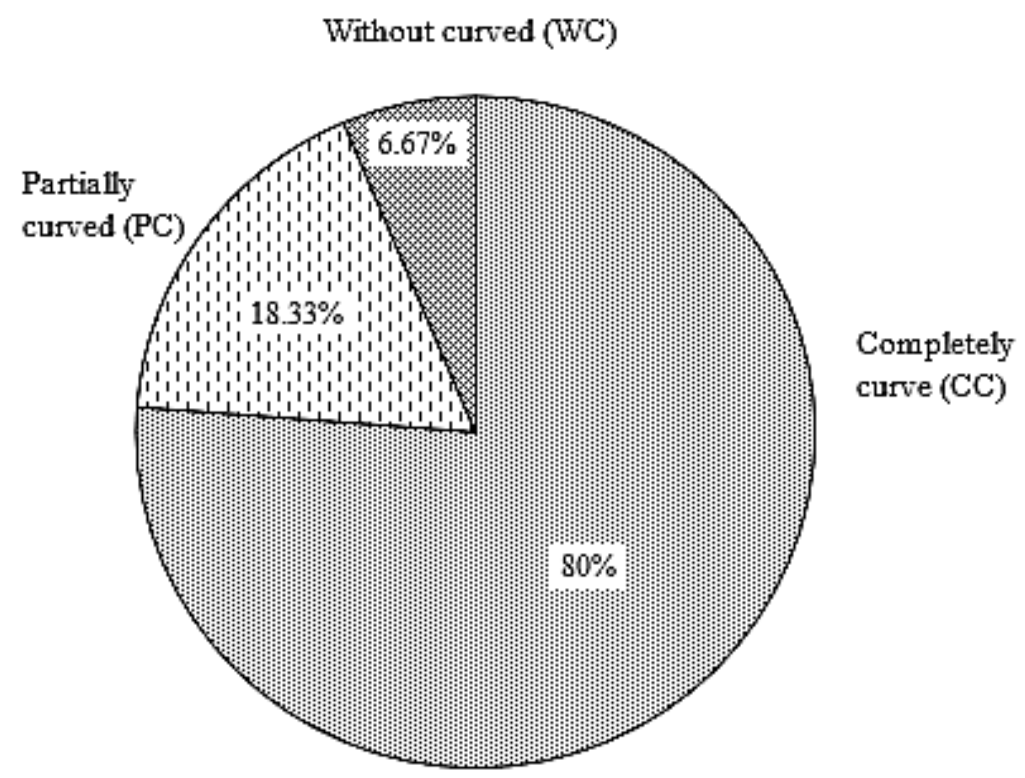

Figure 2. Percentage (\%) of different types of style observed among P. quadrangularis flowers 
unique movement of the styles and position of stigmas and anthers are important for self-pollination, as discussed above. At the present study site, there were good fruit sets, despite pollinators being relatively infrequent and sometimes absent. There were several visitors that helped with pollination; the most common visitors were ant species, which are nectar feeders and not pollinators. Therefore, the studied $P$. quadrangularis species mostly exhibited unique autonomous self-pollination; involving the movement of the styles, causing the stigmas to face the anthers during flower blooming and providing reproductive assurance to the species. The plants were self-compatible and able to produce constant fruit sets during the study period when biotic pollination was limited. According to Knight and Sauls (1994) and Sicard and Lenhard (2011), changes from self-incompatibility to self-compatibility frequently occur in cultivated flowering species. A number of flowering plants (e.g., species of Zingiberaceae such as Roscoea schneideriana (Zhang \& Li, 2008) and orchids (Chen et al., 2012) grow in areas with an insufficient presence of pollinators. The evolution of self-compatibility has generally been interpreted as a strategy for reproductive assurance in the absence or scarcity of pollinators.

\section{Flowers Visitors and Nectar Composition}

The genus of Passiflora includes several cultivated species of economic importance, with Colombia and Brazil as the center of diversification (Cerqueira-Silva et al., 2016). The pollen of $P$. quadrangularis has a sticky texture and is heavy, making wind pollination ineffective (Aguiar-Menezes et al., 2002; Souza et al., 2004). Insects are essential pollinators in certain species of Passiflora as autonomous self-pollination only has a small contribution to the fruit set. For example, autonomous self-pollination only contributed to $4 \%$ of the $P$. ligularis fruit set, as reported by Cataline et al. (2018). The solitary flowers of $P$. quadrangularis bear a single annular ridge-like nectary at the base of the corona, which stores nectar and is covered by an operculum. Sugary nectar is produced for pollinators that visit the flowers. The pollinators observed in this study were classified into three groups based on their sizes. The large pollinators that were observed were butterflies (Cethosia hypsea hypsina) and carpenter bees (Xylocopa sonorina). The medium pollinators were honeybees (Apis millifera) and moths (Amata huebneri). Stingless bees (Trigona sp.) were the only small pollinators recorded among the main visitors. As the pollinators landed on the flat corona and fed on the nectar, their upper bodies had contact with the exposed pollen-bearing surface of the anther. The pollen grains deposited on their wings and thorax then touched the stigma and transferred the pollen grains. It was also observed that ants frequently fed on the nectar produced by $P$. quadrangularis vines. Five ant species were identified as nectar feeders; Technomyrmex sp., Pristomyrmex sp., Componotus sp., Polyrhachis sp., and Pachycondyla sp. 
Each flower produced approximately 22.7-58.0 $\mu \mathrm{L}$ of nectar during phase 2 . Sucrose, glucose, and fructose were the predominant sugar components in $P$. quadrangularis flower nectar. The sugar composition of $P$. quadrangularis was compared with other Passiflora species (Figure 3). The nectar of $P$. quadrangularis was dominated by sucrose (40.78-58.34 g $\left.100 \mathrm{~g}^{-1}\right)$, followed by glucose (4.56-6.43 $\mathrm{g}$

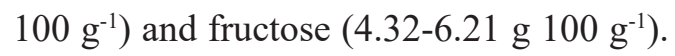
Similar trend was recorded in the nectar composition of $P$. maliformis. In contrast, $P$. incarnata and $P$. edulis (purple) possessed higher reducing sugars; fructose and glucose compared to sucrose. On average, the nectar of $P$. quadrangularis and P. maliformis; sucrose (83-86\%) was dominant followed by glucose $(7-8 \%)$ and fructose $(7-8 \%)$, while the average composition in $P$. edulis and $P$. incarnata was dominated by glucose (34-37\%) and fructose (35-37\%) with least sucrose (26-31\%). According to Garcia and Gottsberger (2009), there are variations in the nectar sugar composition of Passiflora species with fructose and glucose being dominant in $P$. caerulea and $P$. foetida, while sucrose was the dominant sugar in $P$. suberosa. According to the classification by Perez and d'Eeckenbrugge (2017), P. edulis

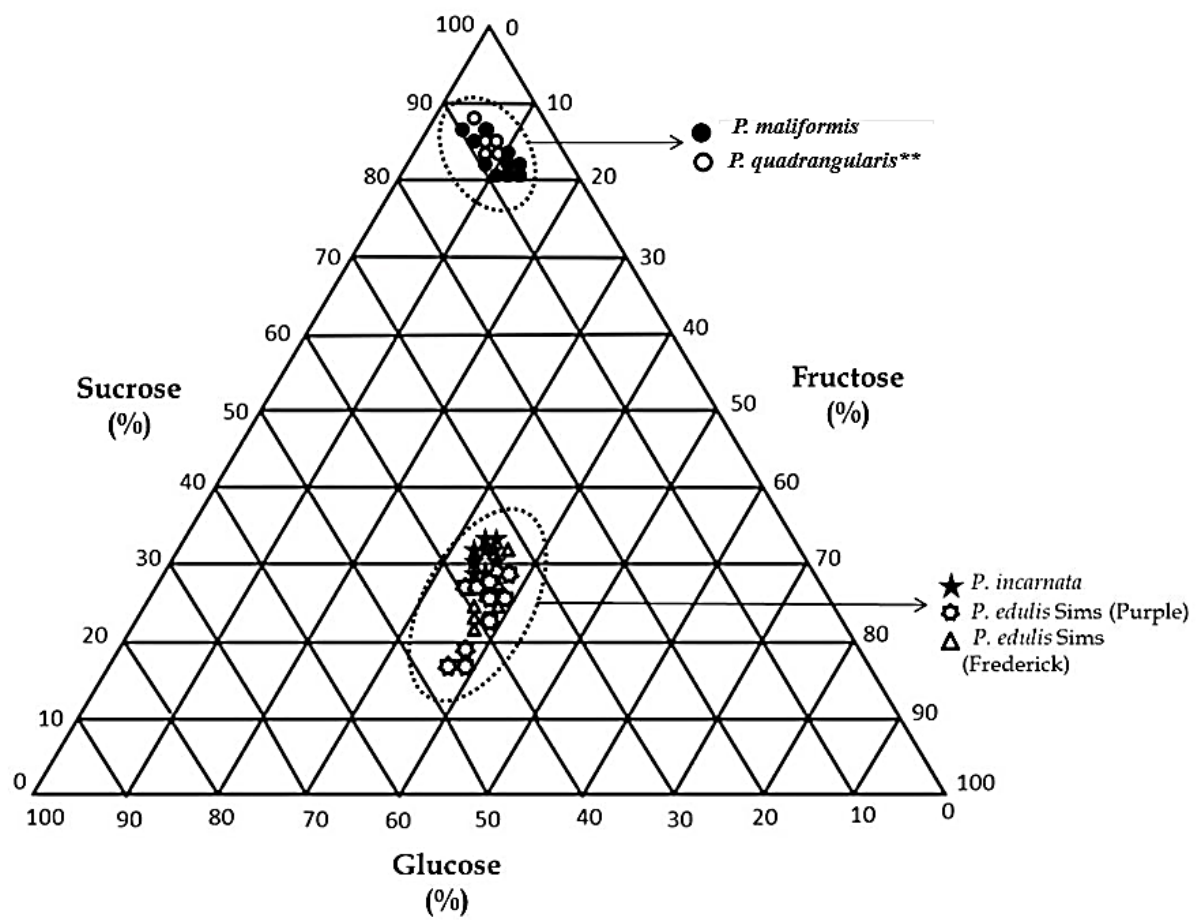

Figure 3. Nectaries sugars (sucrose, glucose and fructose) composition of P. quadrangularis** in comparison with other passion fruit species, illustrated by the ternary diagram 
and $P$. incarnata belong to the Passiflora supersection and $P$. quadrangularis and $P$. maliformis belong to the Laurifolia super-section. The similarity between $P$. edulis and $P$. incarnata and that between $P$. quadrangularis and $P$. maliformis was reflected by their nectar chemistries. According to the authors, the nectar of $P$. edulis and P. incarnata flowers were dominated by glucose and fructose, while those of $P$. quadrangularis and $P$. maliformis flowers were dominated by sucrose. Nevertheless, the composition of sugar may be related to the pollinator type. Koschnitzke and Sazima (1997) mentioned the nectar of P. suberosa (Decoloba subgenus), which is pollinated by wasps in its native distribution, tended to be rich in sucrose, while flowers pollinated by short-tongued bee, e.g., $P$. foetida had a hexose (i.e., glucose and fructose) rich nectar.

\section{Passiflora quadrangularis Fruit Development}

The fruit developed from the ovary was oblong in shape when it matured and showed marked variation in their size, weight, and number of seeds per fruit. After the anthesis, the ovary enlarged, and the fruits developed. Simultaneously, seeds and pulp were also developed. The days required for $P$. quadrangularis fruit ripening was approximately 2 months after anthesis. Upon maturity, the fruit exocarp turned greenish yellow. The pericarp of fruit, which contains the aerial, is formed by three distinct tissues; i) an external epidermis which is smooth and a thin layer of rind; ii) a mesocarp, edible thick, juicy and sweet flesh and iii) the endocarp, which is separated from the mesocarp by an aerenchymatous tissue and has parenchyma tissue. Passiflora quadrangularis produces larger fruit; fruit length $(20.75 \pm 2.26 \mathrm{~cm})$ $\mathrm{X}$ fruit width $(12.24 \pm 1.22 \mathrm{~cm})$ compared to the common passion fruit, i.e., $P$. edulis with fruit length $(7.48 \pm 0.96 \mathrm{~cm}) \mathrm{X}$ fruit width $(6.61 \pm 0.49 \mathrm{~cm})$. The mesocarp of this fruit is edible and taste similar to honeydew. The unripen mesocarp can be cooked as a vegetable (Fischer et al., 2018). While the ripen fruit's pulp is orange in color, sweet in taste and less acidic than the common passion fruit and suitable to make juice and other processed products.

Fruit development phase for $P$. quadrangularis is presented in Figure 4. There are three stages of fruit development. The first stage is the initiation of fruit to begin with cell division and cell expansion. Fruit weights increases rapidly after day 10 of anthesis and attains half of the weight of a ripe fruit on day 20. Stage 2 is called the fruit expansion and maturation. During this stage, arils expand to form a bag which is termed juice-sac, containing yellow to orange juicy pulp and development of seed. Passiflora quadrangularis has four longitudinal rows at the position of the endocarp wall. Stage 3 is the ripening, softening and coloring of fruit and accumulation of soluble solid and acid. At this stage, all chloroplast are masked by color pigments. The sac is its maximum size and weight at this stage. Juice sac increases its size and volume and juice concentration. Our results revealed that $P$. quadrangularis 
achieved complete maturity after $62.6 \pm 1.94$ days ( $\sim 2$ months) of anthesis. Similarly, $P$. edulis also attained maturity after 2 months of anthesis (Nave et al., 2010). Fruit maturity of a crop is influenced by genetic make-up, physiological condition of the specific crop as well as environmental factors such as rainfall, humidity, temperature and day length (Das et al., 2013).

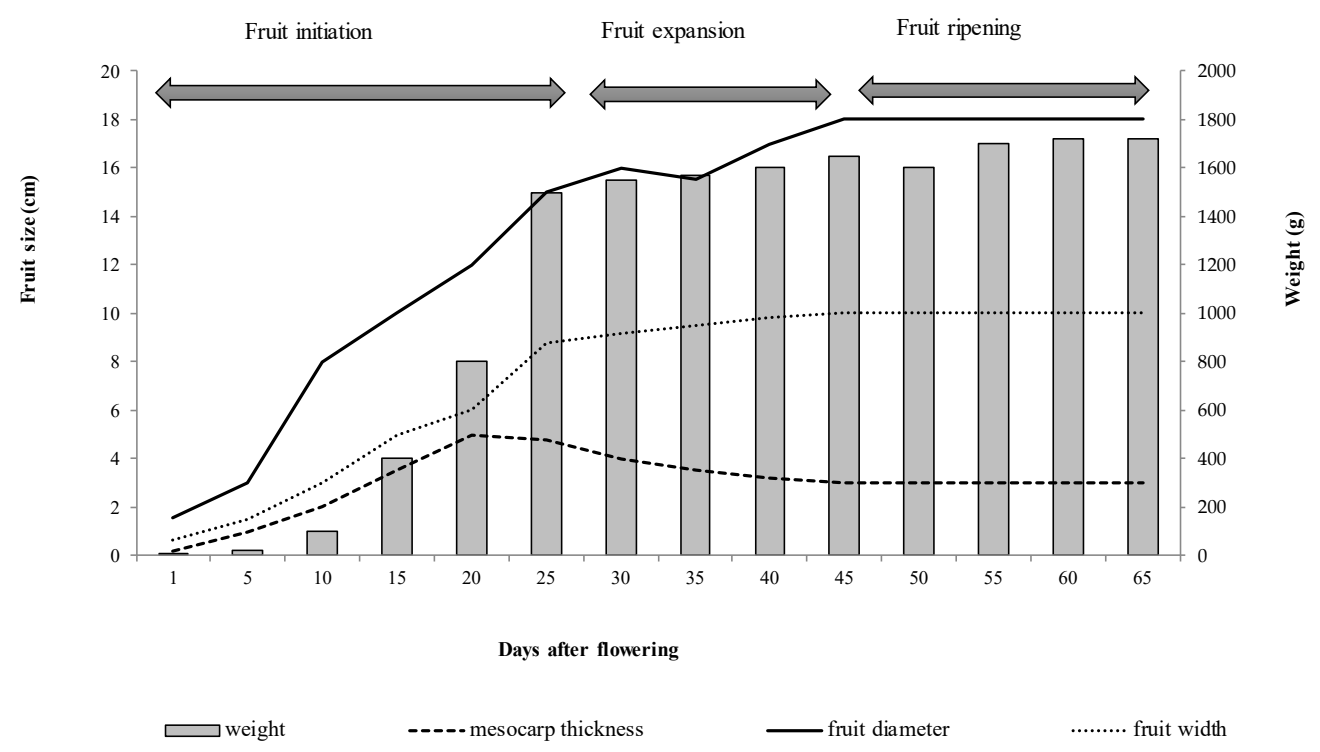

Figure 4. Curve for development of $P$. quadrangularis fruit with time

Passiflora quadrangularis was observed to only flower and fruit at certain months (Figure 5). The major peak was observed in September-November, coinciding with warm temperatures and moderate raining season, and a minor peak in FebruaryMarch. This contrasts with $P$. edulis which produces fruits all year around with three major peaks recorded in April-May, JulySeptember and November-January. Kishore et al. (2010) from India stated that $P$. quadrangualris had three major periods of bloom in March-April, July-August and September-October and this is in contrast to the present finding where there was only a single major peak served in a year.

In its center of origin (South America), the plant produced fruits throughout the year. There were long vegetative periods observed from April to August in P. quadrangularis (Ulmer \& MacDougal, 2004). The long vegetative phase in plants may allow the accumulation of carbohydrate which is later used during flowering and fruiting to 

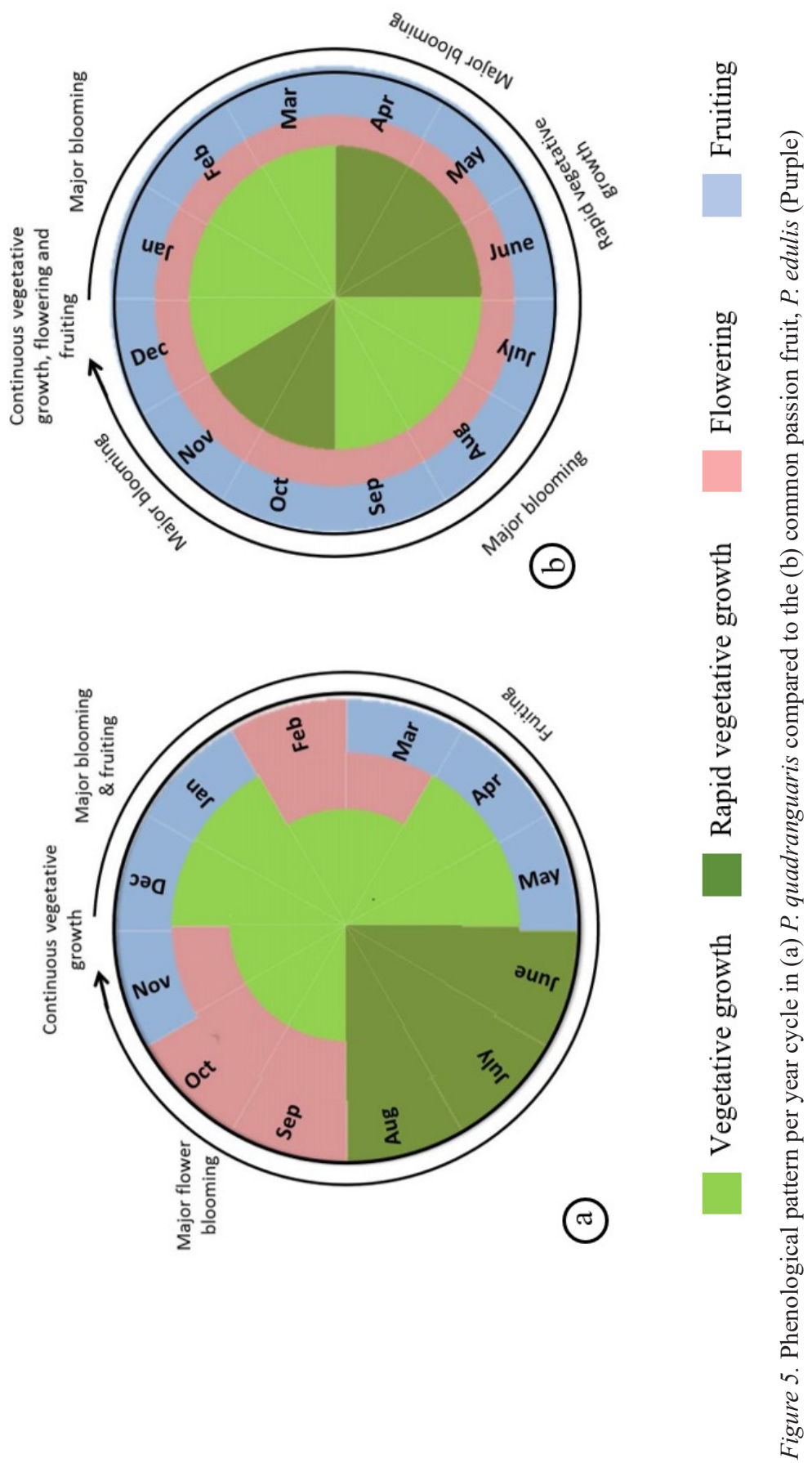
produce heavier fruits. Knight and Sauls (1994) stated this species began to flower in spring and its fruit matured in summer and the fruits weigh 225-450 g under Florida conditions. The reproductive phenological pattern of Passiflora plant was affected by climatic conditions as well as geographic region of cultivation. Moreover, different cultivated Passiflora species respond differently to environmental factors and soil type. The irradiance of the environment in which the plants grow is of fundamental importance, because the adaptation of the plants to this environment depends on the adjustment of their photosynthetic path, so the light is used in a more efficient way (Das et al., 2013; Koehler-Santos et al., 2006). In this study, the production of $P$. quadrangularis produced bigger fruits, which was $20,151.36 \mathrm{~kg} \mathrm{ha}^{-1}$ (8993 fruits) with weights ranging from 884.4 to 2892.7 g. Comparatively, the annual production of $P$. edulis at local climate in East Malaysia is 119,174 fruits of $11,103.90 \mathrm{~kg} \mathrm{ha}^{-1}$ with the weight range of 56.4-156.5 $\mathrm{g}$ (Ramaiya et al., 2020).

\section{CONCLUSION}

According to the findings of the present study, P. quadrangularis was well adapted to the local climate, and its success was reflected in the quantity and quality of the fruit produced. There was no environmental selective pressure constraining the timing of the flowering and fruiting of $P$. quadrangularis. The flowers of this species are known as "steady-state"; meaning that they constantly produce few flowers each day, with each flower lasting only a day. This species undergoes unique autonomous self-pollination involving the movement of the styles and anthers, which assures fruit production regardless of the presence of pollinators. The detailed reproductive biology of $P$. quadrangularis reported here can provide visual clues that farmers can utilize to time farming operations in local cultivation practices and planting management. In addition, this information will also help further research on breeding and increasing production of $P$. quadrangularis.

\section{ACKNOWLEDGEMENTS}

This study was funded by Universiti Putra Malaysia under GP-IPM/2018, entitled 'Biology, Cultivation and Potential Uses of P. quadrangularis L. (Giant Granadilla Passion Fruit)'. We are grateful to American Journal Expert, for revising and checking the English in this paper.

\section{REFERENCES}

Aguiar-Menezes, E. L., Menezes, E. B., Cassino, P. C. R., \& Soares, M. A. (2002). Passion fruit. In J. L. Sharp, \& M. Wysoki (Ed.), Tropical fruit pests and pollinators: Biology, economic importance, natural enemies and control (pp. 361-390). London, UK: CABI Publishing.

Altendorf, S. (2018). Minor tropical fruits: Mainstreaming a niche market. Retrieved October 20, 2019, from http://www.fao.org/ fileadmin/templates/est/COMM_MARKETS MONITORING/Tropical_Fruits/Documents/ Minor_Tropical_Fruits_FoodOutlook_1_2018. pdf. 
Banu, M. B., Matin, M. Q. I., \& Hossain, T. (2009). Flowering behaviors and flower morphology of passion fruit. International Journal of Sustainable Crop Production, 4(4), 5-7.

Bruckner, C., Casali, V., Moraes, C., Regazzi, A., \& Silva, E. (1995) Self-incompatibility in passion fruit (Passiflora edulis Sims). Acta Horticulturae, 370, 45-57. doi: 10.17660/ ActaHortic.1995.370.7

Catalina, G., Felix, F., Rodulfo, O., \& Alexandra, K. (2018). Pollination of granadilla (Passiflora ligularis) benefits from large wild insect. Journal of Economic Entomology, 111(4), 1526-1534. doi: $10.1093 /$ jee/toy133

Cerqueira-Silva, C. B. M., Faleiro, F. G., de Jesus, O. N., dos Santos, E. S. L., \& de Souza, A. P. (2016). The genetic diversity, conservation, and use of passion fruit (Passiflora spp.). In M. R. Ahuja, \& S. Mohan Jain (Ed.), Genetic diversity and erosion in plants (pp. 215-231). Cham, Switzerland: Springer. doi: 10.1007/978-3-31925954-3_5

Chai, T. (1979). Passion fruit culture in Malaysia: Fruit research branch. Pahang, Malaysia: Malaysia Agricultural Research and Development Institute (MARDI)

Chen, L. J., Liu, K. W., Xiao, X. J., Tsai, W. C., Hsiao, Y. Y., Huang, J., \& Liu, Z. J. (2012) The anther steps onto the stigma for self-fertilization in a slipper orchid. PLoS One, 7(5), 1-6. doi: 10.1371/journal.pone.0037478

Das, M. R., Hossain, T., Baset Mis, M. A., Ahmed, J. U., Sirajul Karim, A. J. M., \& Hossain, M. M. (2013). Fruit setting behaviour of passion fruit. American Journal of Plant Science, 4(5), 10661073. doi: 10.4236/ajps.2013.45132

Fischer, G., Melgarejo, L. M., \& Culter, J. (2018). Pre-harvest factors that influence the quality of passion fruit: A review. Agronomía Colombiana, 36(3), 217-226. doi: 10.15446/agron.colomb. v36n3.71751
Garcia, M. T. A., \& Gottsberger, G. (2009). Composition of the floral nectar of different subgenera of Argentinian Passiflora species. Plant Systematics and Evolution, 283, 133-147. doi: 10.1007/s00606-009-0215-3

Gonzalez, V. H., Gonzalez, M. M., \& Cuella, Y. (2009). Notas biologicas y taxonomicas sobre los abejjoros del maracuya del genero Xylocarpa (Hymenoptera: Apidae, Xylocopini) en Colombia [Biological and taxonomic notes on maracuyá bees of the genus Xylocopa (Hymenoptera: Apidae, Xylocopini) in Colombia]. Acta Biologica Colombiana, 14(2), 31-40.

Gratani, L. (2014). Plant phenotypic plasticity in response to environmental factors. Advances in Botany, 2014 (4), 1-17. doi: 10.1155/2014/208747

Haddad, O., \& Figueroa, M. (1972). Estudio de la Floración y Fructificación en parcha granadilla Passiflora quadrangularis L. [A study of flowering and fructification of granadilla (Passiflora quadrangularis L.)]. Agronomia Tropical, 22(5), 483-496.

Ingale, A. G., \& Hivrale, A. U. (2010). Pharmacological studies of Passiflora sp. and their bioactive compound. African Journal of Plant Science, 4(10), 417-426. doi: 10.5897/AJPS.9000185

Joy, P. P., (2010). Status and prospects of passion fruit cultivation in Kerala: Pineapple research station. Kerala, India: Kerala Agricultural University.

Kishore, K., Pathak, K. A., Shukla, R., \& Bharali, R. (2010). Studies on floral biology of passion fruit (passiflora spp.). Pakistan Journal of Botany, 42(1), 21-29.

Knight, R. J., \& Sauls, J. W. (1994). The passion fruit. Gainesville, Florida: Florida Cooperative Extension, University of Florida.

Koehler-Santos, P., Lorenz-Lemke, A., Salzano, F., \& Freitas, L. (2006). Ecological-evolutionary relationships in passiflora from Rio Grande 
do Sul, Brazil. Brazilian Journal of Biology, 66(3), 809-816. doi: 10.1590/S151969842006000500006

Koschnitzke, C., \& Sazima, M. (1997). Biologia floral de cinco especies de Passiflora L. (Passifloraceae) en mata semidecidua [Floral biology of five species of Passiflora L. (Passifloraceae) in a semideciduous forest]. Brazilian Journal of Botany, 20(2), 199-226. doi: 10.1590/S010084041997000200002

Li, H. X. Gao, R. Zheng, J., Zhang, J. J., Zhang, D. W., Dong, Z. C., Zhou, T., \& Li, H. B. (2016). Bioactivities of passion fruit. International Journal of Traditional and Natural Medicine, 6(1), 26-34.

Madureira, H., Pereira, T., Cunha, M., Klein, D., Oliveira, M., Mattos, L., \& Souza, F. (2014) Self-incompatibility in passion fruit: Cellular responses in incompatible pollinations. Biologia, 69(5), 574-584. doi: 10.2478/s11756-014-0353-0

Martina, R., Marcos, R. O., Tiago, P., Flavio, H. R., Felipe, D., \& Jose F. M. (2007). Antioxidant and antiglycation properties of Passiflora alata $\mathrm{m}$ and Passiflora edulis extracts. Food Chemistry, 100(2), 719-724. doi: 10.1016/j. foodchem.2005.10.043

Martínez, R., Torres, P., Meneses, M. A., Figueroa, J. G., Pérez-Álvarez, J. A., \& Viuda-Martos, M. (2012). Chemical, technological and in vitro antioxidant properties of mango, guava, pineapple and passion fruit dietary fibre concentrate. Food Chemistry, 135(3), 15201526. doi: 10.1016/j.foodchem.2012.05.057

Meier, U., Bleiholder, H., Buhr, L., Feller, C., Hacks, H., Hess, M., ... \& Zwerger, P. (2009). The $\mathrm{BBCH}$ system to coding the phenological growth stages of plants-history and publications. Journal für Kulturpflanzen, 61(2), 41-52.

Min, J., Watson, R. S., Farid, R., \& Foo, Y. (2011). Passion fruit extract in osteoarthritis symptom treatment. Agrofood Industry hi-tech. 22(2), 24-29.

Montero, D. A. V., Meletti, L. M. M., \& Marques, M. O. M. (2013). Flowering behavior of five species of Passiflora cultivated at greenhouse in Southeast Brazil. International Journal of AgriScience, 3(3), 176-181.

Morellato, L. P. C., \& Haddad, C. F. P. (2000). Introduction: The Brazilian Atlantic forest. Biotropica, 31, 786-792. doi: 10.1111/j.17447429.2000.tb00618.x

Nave, N., Katz, E., Chayut, N., Gazit, S., \& Samach, A. (2010). Flower development in the passion fruit Passiflora edulis rquires a photoperiodinduced systemic graft-tranfmissible signal. Plant Cell and Environmental, 33(12), 20652083. doi: 10.1111/j.1365-3040.2010.02206.x

Patel, S. S., Soni, H., Mishra, K., \& Singhai, A. K. (2011). Recent updates on the genus Passiflora: A review. International Journal of Research in Phytochemistry and Pharmacology, 1(1), 1-16.

Perez, J. O., d'Eeckenbrugge, G. C., Restrepo, M., Jarvis, A., Salazar, M., \& Caetano, C. (2007). Diversity of Colombia passifloraceae: Biogeography and an updated list for conservation. Biota Colombiana, 8(1), 1-45.

Perez, J. O., \& d'Eeckenbrugge, G. C. (2017). Morphological characterization in the genus Passiflora L.: An approach to understanding its complex variability. Plant Systematics and Evolution, 303(4), 531-558. doi: 10.1007/ s00606-017-1390-2.

Phamiwon, Z. A. S., \& John, S. (2015). Diabetes and medicinal benefits of Passiflora edulis. World Journal of Pharmaceutical Research, 5(3), 453-659.

Ramaiya, S. D., Bujang, J. B., Zakaria, M. H., \& Saupi, N. (2019). Nutritional, mineral and organic acid composition of passion fruit 
(Passiflora species). Food Research, 3(3), 231240. doi: 10.26656/fr.2017.3(3).233

Ramaiya, S. D., Bujang, J. S., Zakaria, M. H., \& Shahirah, N. (2020). Floral behaviour, flowering phenology and fruit production of Passion Fruit (Passiflora Species). Journal of Agriculture Food and Development, 6, 1-9. doi: 10.30635/24150142.2020.06.01

Ramaiya, S. D., Bujang, J. S., Zakaria, M. H., King, W. S., \& Sahrir, M. A. S. (2013). Sugars, ascorbic acid, total phenolic content and total antioxidant activity in passion fruit (Passiflora) cultivars. Journal of the Science of Food and Agriculture, 93(5), 1198-1205. doi: 10.1002/jsfa.5876

Ripa, F. A., Haque, M., Nahar, L., \& Islam, M. M. (2009). Antibacterial, cytotoxic and antioxidant activity of Passiflora edulis Sims. European Journal of Scientific Research, 31(4), 592-598.

Salazar, A. H., Silva, D. F., \& Bruckner, C. H. (2016). Effect of two wild rootstocks of genus Passiflora L. on the content of antioxidants and fruit quality of yellow passion fruit. Bragantia, 75(2), 164172. doi: 10.1590/1678-4499.396

Shaffiq, S., Sidik, B. J., Harah, Z. M., \& Devi, R. S. (2013). Marketable wild fruits of Sarawak, Borneo: Their mode of consumption, uses and sugar profiles. Indian Journal of Traditional Knowledge, 12(2), 195-201.
Shivanna, K. R. (2012). Reproductive assurance through unusual autogamy in the absence of pollinators in Passiflora edulis (passion fruit). Current Science, 103(9), 1091-1096.

Sicard, A., \& Lenhard, M. (2011). The selfing syndrome: A model for studying the genetic and evolutionary basis of morphological adaptation in plants. Annals of Botany, 107(9), 1433-1443. doi: 10.1093/aob/mcr023

Souza, M., Pereira, S., Viana, A., Pereira, G., Junior, A. T. D., \& Madureira, H. (2004). Flower receptivity and fruit characteristic associated to time of pollination in the yellow passion fruit Passiflora edulis sims degener (Passifloracea). Scientia Horticultura, 101(4), 373-385. doi: 10.1016/j.scienta.2003.11.020

Ulmer, T., \& MacDougal, J. M. (2004). Passiflora: Passionflowers of the world. Portland, Oregon: Timber Press.

Zhang, Z. Q., \& Li, Q. J. (2008). Autonomous selfing provides reproductive assurance in an alpine ginger Roscoea schneideriana (Zingiberaceae). Annals of Botany, 102(4), 531-538. doi: 10.1093/aob/mcn 136 